\title{
KOEKSISTENSI ANTARA ARSITEKTUR BUGIS MAKASSAR DENGAN ARSITEKTUR MODEREN PADA BANGUNAN KANTOR PEMERINTAHAN DI KOTA MAKASSAR
}

\author{
Citra Amalia Amal ${ }^{1}$; Andi Fitriyah Azsahrah² \\ Universitas Muhammadiyah Makassar (pure_citra@yahoo.com) ${ }^{1}$; \\ Inspirasi Arsitek Konsultan (fitriyahazsahrah@gmail.com)²
}

\begin{abstract}
ABSTRAK
Penelitian ini bertujuan untuk menjelaskan hubungan koeksistensi antara arsitektur Bugis Makassar dengan arsitektur Moderen berkaitan identitas arsitektur lokal dan bentukan fisik pada kantor pemerintah, serta menemukenali unsur-unsur Bugis Makassar dan arsitektur moderen yang mengalami koeksistensi pada kantor pemerintahan di Kota Makassar. Penelitian bersifat deskriptif yang dianalisis secara kualitatif. Adapun bangunan kantor pemerintahan yang diteliti yaitu Kantor Gubernur Provinsi Sulawesi Selatan, Kantor DPRD Kota Makassar, dan Kantor Bank BTN Cabang Makassar. Hasil penelitian menunjukkan bahwa ketiga bangunan pemerintahan tersebut mengadopsi prinsip arsitektur Bugis Makassar secara spasial vertikal (kepala, badan, dan kaki), sedangkan secara spasial horisontal tidak menerapkan prinsip arsitektur Bugis Makassar. Untuk struktur bangunan tidak menerapkan struktur arsitektur Bugis Makassar. Pemakaian material dan teknologi yang moderen menyebabkan terjadinya perubahan proporsi dan dimensi, tetapi secara bentuk tetap menerapkan bentuk arsitektur tradisional Bugis Makassar.
\end{abstract}

Kata Kunci : arsitektur bugis makassar, arsitektur modern, koeksistensi

\section{PENDAHULUAN}

Arsitektur merupakan salah satu wujud dari budaya dan sekaligus bagian dari kebudayaan. Menurut Koetjaraningrat (1996) kebudayaan sendiri terdiri dari 7 unsur budaya yaitu: bahasa, kesenian, sistem mata pencaharian, sistem teknologi, sistem religi, sistem dan organisasi masyarakat dan sistem pengetahuan. Arsitektur dibangun untuk mampu menjawab kebutuhan manusia dan mengangkat derajat hidupnya menjadi lebih baik, sehingga tidak dapat dilepaskan dari perkembangan kebudayaan.

Menurut Budiharjo (1995) Indonesia kaya akan warisan kultural termasuk kehandalan arsitektur daerahnya di berbagai tempat dan mampu menjadi identitas budaya daerah. Bukti sejarah menunjukkan bahwa jauh sebelum globalisasi melanda, arsitektur di Indonesia telah membuka diri terhadap pengaruh budaya lain melalui proses adaptasi dan akulturasi yang telah berlangsung lama. Kekuatan eksternal selalu membawa pengaruh pada arsitektur terutama pada faktor budaya, sosial, ekonomi dan teknologi yang merupakan faktor dinamis, sedangkan faktor yang relatif konstan seperti iklim, letak geografis, dan kondisi geologis.

Untuk eksis dalam arus globalisasi maka budaya tradisional perlu dipertautkan dengan budaya modern yang juga dikenal dengan istilah koeksistensi agar sejalan dengan perubahan tatanan sosial masa kini yang dapat memperkuat arsitektur Indonesia moderen yang memiliki identitas nasional. Oleh karena itu, menurut Budiharjo (1995) penting untuk melestarikan nilai-nilai dari arsitektur tradisional sebagai pusaka budaya karena kehilangan identitas arsitektur tradisional berarti kehilangan identitas budaya bangsa.

Sebagai pusat pemerintahan dan ibukota Propinsi Sulawesi Selatan, Kota Makassar memiliki banyak sekali gedung perkantoran khususnya kantor pemerintahan. Beberapa bangunan kantor pemerintahan tersebut mencoba mengaplikasikan bangunan dengan bentukan fisik yang memadukan dan mengadopsi elemen arsitektur tradisional dan moderen dengan tujuan menguatkan identitas dan mengangkat ciri khas arsitektur lokal yaitu Bugis-Makassar. Akan tetapi, hasil aplikasi penerapan arsitektur tradisional pada bangunan moderen tersebut terjadi perubahan geometri, volume, teknologi, material, kontruksi dan orientasi.

Problema yang mungkin terjadi dalam aplikasi kedua style/gaya arsitektur tersebut, ada yang berhasil menghadirkan bangunan sarat makna dan identitas arsitektur lokal namun ada pula yang menghasilkan produk eklektik yang penerapannya terkesan tempel sehingga secara visual tidak mencerminkan kesinambungan dalam berasitektur sehingga proses koeksistensi arsitektur antara keduanya tidak tercapai atau dengan kata lain 
dipaksakan.

Berdasarkan uraian di atas, ditarik hipotesis bahwa ada keinginan untuk mengembangkan serta mengadopsi arsitektur tradisional dan penerapannya pada bangunan pemerintahan, namun fenomena yang terjadi penerapan bentuk dan makna simbolik itu tidak terwadahi dengan maksimal, hal ini diduga disebabkan oleh kurangnya kepekaan dan pemahaman para perencana juga penentu kebijakan dalam menerapkan bentuk dan pemaknaan arsitektur lokal pada bangunan moderen terutama pada bangunan kantor pemerintah.

\section{TINJAUAN PUSTAKA}

\section{Kebudayaan dan Arsitektur}

Arsitektur merupakan hasil karya manusia sebagai tanggapan terhadap adaptasi manusia terhadap lingkungannya. Arsitektur dibangun untuk mampu menjawab kebutuhan manusia dan mengangkat derajat hidupnya menjadi lebih baik, sehingga tidak bisa dilepaskan dari perkembangan kebudayaannya.

Menurut Rapoport (1969) arsitektur itu sendiri adalah buah dari budaya yang dikembangkan secara terus-menerus, sejalan dengan pendapat Shoemaker dalam Fanani (2009) bahwa arsitektur adalah buah refleksi potensi rohani yang hidup di dalam suatu masyarakat, tak ada perwujudan karya yang lebih jelas dalam menggambarkan situasi kebudayaan suatu kelompok masyarakat, bahkan sampai ke pandangan hidup dan cita-cita keyakinannya, kecuali arsitektur.

\section{Arsitektur Bugis Makassar}

Arsitektur Bugis Makassar yang merupakan bagian dari arsitektur tradisional yang ada di Indonesia mempunyai filosofi dan konsep yang hampir sama dengan arsitektur tradisional yang ada di Nusantara yang sarat dengan makna simbol dari kosmologinya. Filosofi arsitektur Bugis Makassar mengandung nilai falsafah, nilai ekonomi politik, nilai status sosial, nilai kesatuan hidup keluarga, dan nilai estetika.

Penataan secara spasial vertikal rumah Bugis Makassar, sebagai berikut :

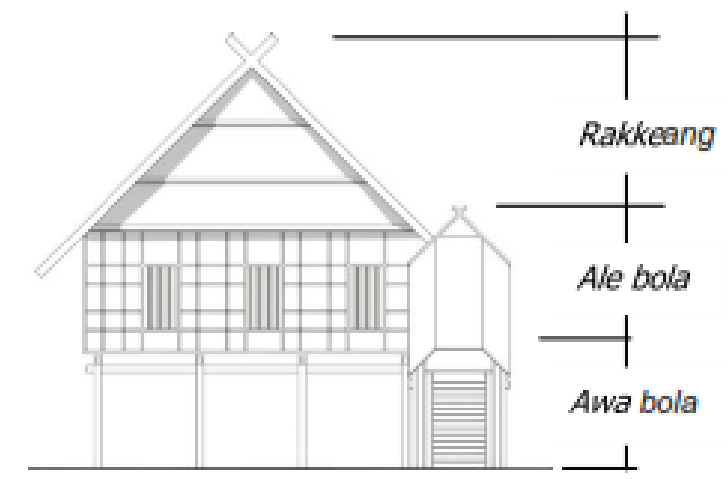

Gambar 1. Penataan Spasial Vertikal Rumah Bugis Makassar

Penataan secara spasial horisontal (berdasarkan Bola-Soba, Bone) :

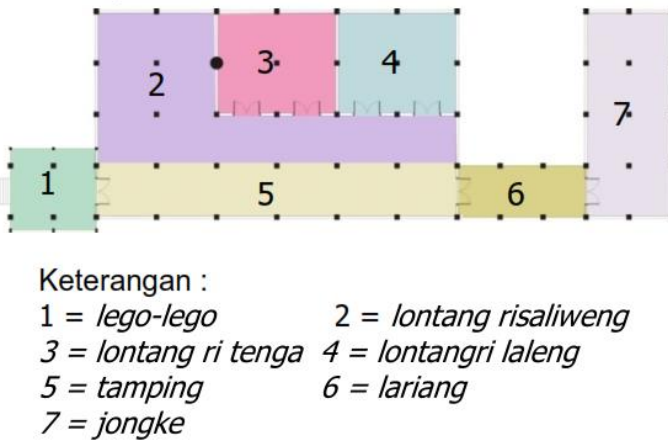

Gambar 2. Penataan Spasial Horisontal Rumah Bugis Makassar

Rumah tradisional Bugis dan Makassar mempunyai banyak persamaan dan hanya sedikit perbedaan, baik dari segi konstruksi maupun dari segi bentuk. Keduanya membedakan tipe-tipe rumah rakyat biasa dengan rumah kaum bangsawan atau raja. Begitu pula fungsi sosial si pemilik diperlihatkan pada bangunan rumahnya. Rumah raja biasanya lebih besar, baik ruangannya maupun bahan dan materialnya. Sehingga, melalui bentuk rumah dapat diketahui kedudukan penghuninya.

Masyarakat Bugis Makassar menganggap rumah adalah diri mereka sendiri, sehingga ukuran atau modul rumah yang mereka gunakan berdasar dari ukuran tubuh mereka sendiri (pemilik bangunan), memperlihatkan fungsi sosial bagi penghuninya, makna dan filosofi yang terkandung dari bentuk, struktur serta ornamen arsitektur rumah Bugis Makassar.

\section{Arsitektur Moderen}

Kata moderen selalu dikaitkan dengan baru atau mutakhir, termasuk di dalamnya sikap dan cara berpikir dan bertindak sesuai 
dengan tuntutan jaman. Sehingga, sesuatu yang moderen selalu menjadi harapan yang ingin dicapai seseorang, demikian pula arsitektur moderen diharapkan dapat melahirkan suatu nilai-nilai baru yang dapat memenuhi tuntutan pewadahan dari aktivitas masyarakat yang selalu berkembang dan menginginkan perbaikan sejalan dengan kemajuan peradabannya.

\section{Koeksistensi Arsitektur}

Definisi koeksistensi menurut Echols (1976) adalah coexist yang berarti hidup bersama, berdampingan, coexistence yang berarti hidup berdampingan secara damai.

Koeksistensi menurut Kamus Besar Bahasa Indonesia dalam ilmu politik adalah keadaan hidup berdampingan secara damai antara dua negara (bangsa) atau lebih yang berbeda atau bertentangan pandangan politiknya. Berdasarkan pengertian tersebut dapat ditarik kesimpulan bahwa koeksistensi dalam ilmu arsitektur ialah proses kerjasama antar dua atau lebih gaya/style arsitektur yang berbeda tanpa saling mendominasi atau dengan kata lain saling bersinergi.

\section{Koeksistensi Arsitektur Tradisional dan Moderen}

Arsitektur dikembangkan untuk bisa menjawab kebutuhan masyarakat masa kini, baik berupa kebutuhan perlindungan, kebutuhan akan rasa aman, kebutuhan akan lingkungan akrab dan kebutuhan akan harga diri. Menurut Antariksa (2007), arsitektur adalah merupakan salah satu unsur kebudayaan, dan di Indonesia kebudayaan tidak menunjukkan suatu kesatuan yang homogen, tapi menunjukkan keanekaragaman yang sifatnya regional. Nilai-nilai simbolik mempunyai makna yang bertolak dari suatu pandangan hidup tertentu. Penggunaan bentuk-bentuk arsitektur tradisional tanpa memahami nilai-nilai yang terdapat di dalamnya, terasa sangat sukar untuk membuahkan karya arsitektur yang mampu memikul identitasnya.

Perpaduan tradisional dan moderen, menurut Budiharjo (1997) adalah adaptasi arsitektur tradisional dalam kehidupan moderen harus dilakukan sebagai senyawa yang tuntas dan total, bukan hanya sekedar penggabungan suatu penjajaran antara yang lama dan baru. Kaidah-kaidah perancangan tradisional menurutnya patut disenyawakan dengan teknologi canggih, bahan bangunan baru dan tuntutan zaman. Tidak menyiratkan unsur tradisionalnya diambil hanya tempelan fisik semata.

Sama halnya dengan pendapat Prijotomo (1998) yang menyatakan bahwa suatu karya arsitektur dapat dirasakan dan dilihat sebagai karya yang bercorak Indonesia bila karya ini mampu untuk:

a. Membangkitkan perasaan dan suasana ke-Indonesiaan lewat rasa dan suasana.

b. Menampilkan unsur dan komponen arsitektural yang nyata-nyata nampak corak kedaerahannya, tetapi tidak hadir sebagai tempelan atau tambahan (topi) saja.

\section{METODOLOGI}

Metode yang digunakan dalam penelitian adalah deskriptif dengan berdasar pada survey lapangan, observasi, dan wawancara kemudian dianalisis secara kualitatif. Penentuan kasus dilakukan dengan menetapkan beberapa kriteria. Antara lain, merupakan bangunan kantor pemerintahan yang melaksanakan aktivitas administrasi, kebijakan dan jasa di bidang ekonomi, memiliki bentuk khas arsitektur Bugis Makassar pada fasade bangunannya. Kasus terpilih berjumlah 3 (tiga), yaitu : Kantor Gubernur Provinsi Sulawesi Selatan, Kantor DPRD Kota Makassar, Kantor Bank BTN Cabang Kota Makassar.

\section{HASIL DAN PEMBAHASAN \\ Kantor Gubernur Provinsi Sulawesi Selatan \\ Fungsi}

Sebagai kantor bangunan pemerintah yang melambangkan suatu kekuasaan dengan kegiatan melayani masyarakat umum untuk kepentingan pembangunan, pengumpulan data dan administrasii pemerintahan, maka kantor ini telah berfungsi sebagai fungsi physical control, functional frame, social millieu, dan cultural symbolization (berdasar pandangan Schultz).

1) Physical control

Desain pada kasus ini berupaya untuk menyatukan antara lingkungan alam/ekologi dengan lingkungan buatan. Penggunaan atap yang lebar sebagai fungsi kontrol terhadap karakter lingkungan dimana bangunan berada. Penggunan dinding sebagai filter untuk melindungi penghuni/pemakai terhadap 
panas, jendela dan pintu berfungsi sebagai elemen-elemen yang menghubungkan dan memutuskan.

\section{2) Functional frame}

Fungsi tercapai dengan terwadahinya fungsi-fungsi kegiatan dengan pengoptimalan hubungan ruang yang efisien dan efektif. Fungsi telah diterapkan pada kasus ini dengan penggunaan unsur-unsur budaya lokal.

\section{3) Cultural symbolization}

Fungsi telah diterapkan pada kasus ini dengan penggunaan unsur budaya lokal.

4) Social millieu

Kantor Gubernur Provinsi Sulawesi Selatan mampu memperlihatkan, mengaktualisasikan fungsinya sebagai wadah yang memperlihatkan status sosial/tingkatan dari bangunan sebagai kantor pemerintah daerah yang tertinggi dengan memperlihatkan bentuk bangunan sebagai bangunan pemerintahan dengan skala monumental dan prinsip simetris untuk menguatkan kesan formal dan menempatkan portico pada bagian depan yang merupakan adopsi bentuk bangunan pemerintahan pada zaman klasik dan bentuk lego-lego pada bangunan arsitektur Bugis Makassar.

\section{Bentuk}

Secara spasial vertikal, bangunan kantor Gubernur Provinsi Sulawesi Selatan memperlihatkan bentuk dengan karakteristik rumah panggung yang menganologikan bentuk manusia yang terdiri dari kaki (awa bola), badan (ale bola), kepala (rakkeang). Ketegasan bentuk dengan kolom-kolom bagian luar/tepi yang terbebas dari dinding sehingga memberikan kesan kolong, dan bentuk bangunan yang terangkat ke atas.

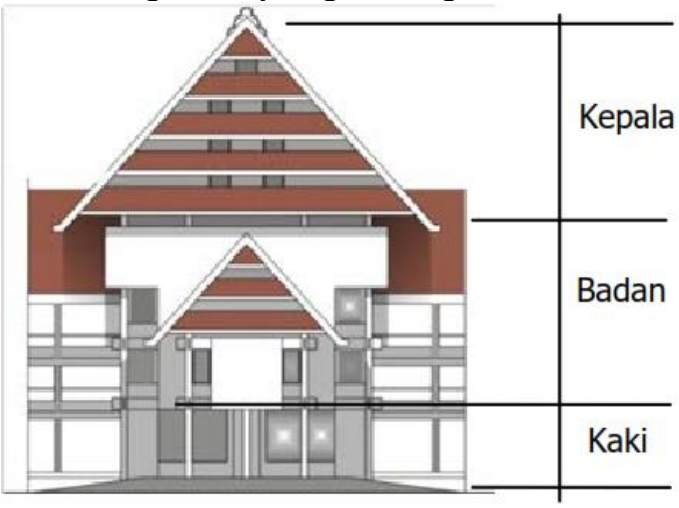

Gambar 3. Penataan Spasial Horisontal Kantor Gubernur Sulsel
Secara spasial horisontal, penataan massa menyebar berdasarkan empat penjuru mata angin yang tersebar pada jarak tertentu sehingga tercipta ruang luar antar bangunan dan terbentuk taman yang menjadi innercourt untuk mengalirkan udara di antara bangunan sehingga bangunan ini telah merespons potensi lingkungan alam. Komposisi penataan massa yang menyebar kemudian membentuk komposisi tata massa secara simetris pada tapak.

Tata massa yang terbentuk saling terpisah namun dihubungkan dengan selasar terbuka sebagai integrasi antar bangunan. Massa bangunan untuk tiap-tiap denah berbentuk persegi panjang dan ramping agar memaksimalkan pencahayaan dan ventilasi silang dapat terbentuk di dalam bangunan.

Filosofi antara posisi pemerintah dengan masyarakat digambarkan melalui permainan tinggi-rendah massa, salah satunya dengan meletakkan ruang kerja gubernur lebih rendah dari bangunan kantor unit kerja masyarakat. Penempatan ruang kerja gubernur lebih rendah sebagai simbolisasi kedekatan pemimpin dan rakyat.

Secara Stilistika:

1) Atap

Pada bagian atap tersusun atas lima timpa laja yang memvisualkan dan memberikan makna status strata sosial tinggi (pemimpin/raja). Atap dengan timpalaja susun lima memiliki makna bahwa seorang pemimpin/raja haruslah memiliki lima hal yaitu seorang pemimpin haruslah menaati adat (ade'), undang-undang (rapang), tatanan hidup (wari), peradilan (bicara), dan syariat (syara').

Kemiringan atap yang mengikuti kaidah arsitektur Bugis Makassar yaitu dengan kemiringan kurang lebih 45은 merupakan hasil perpaduan dari bentuk proporsi (perbandingan lebar bangunan dan tinggi bangunan) yang diterapkan pada bangunan Kantor Gubernur Sulawesi Selatan. Penggunaan tritisan yang panjang merupakan bentuk jawaban dari alam tropis yang terdiri dari dua iklim. Tritisan yang panjang merupakan karakteristik rumah Bugis Makassar untuk menyesuaikan dengan lingkungan.

2) Bukaan

Dinding pada bangunan ini berkesan masif terbuat dari material batu bata 
berorientasi pada arsitektur moderen.

Pada dinding yang diantarai oleh kolom ditempatkan jendela-jendela yang merupakan material dari alam yaitu kayu yang berderet menguatkan kesan repetisi dan berkesan terbuka. Pada bagian kepala/atap terdapat ventilasi yang berfungsi untuk memasukkan udara dan angin.

3) Ornamen

Pada kasus ini ornamen diterapkan pada puncak atap atau biasa disebut dengan anjong terdapat ornamen ayam jantan yang pada arsitektur Bugis Makassar merupakan kaidah dari arsitektur Bugis Makassar sedangkan pada sisi tepi bawah atap yang merupakan penambahan ornamen yang bukan berdasarkan kaidah dalam arsitektur Bugis Makassar tetapi merupakan modifikasi baru dalam perletakan ornamen.

\section{Struktur}

Pada kantor Gubernur Provinsi Sulawesi Selatan, penggunaan struktur dan konstruksi menggunakan sistem struktu rangka yang menggunakan konstruksi dari baja dan beton bertulang. Penggunaan lift berperan sebagai penghubung sirkulasi vertikal antar lantai selain tangga. Dengan demikian maka pada kasus kantor Gubernur Sulsel ini secara struktur dan konstruksi serta building system menggunakan prinsip arsitektur moderen yang telah menggunakan unsur-unsur teknologi.

Kolom-kolom yang digunakan semuanya berbentuk bujursangkar (persegi empat sama sisi), ini mengadopsi bentuk kolom-kolom Bugis Makassar yang merupakan pengejahwantahan konsep struktur tradisional yang ada di Indonesia.

\section{Kantor DPRD Kota Makassar Fungsi}

Sebagai kantor perwakilan rakyat tingkat kota, kantor ini melambangkan simbol demokrasi. Fungsi-fungsi yang terpenuhi pada indikator fungsi functional frame, social millieu tetapi tidak pada cultural symbolization disebabkan tidak adanya unsurunsur yang menguatkan simbol-simbol pada bangunan sebagai cultural symbolization.

\section{1) Functional frame}

Sebagai kantor yang merupakan perwakilan rakyat maka fungsi telah terpenuhi dengan penerapan bentuk yang mengadopsi bentuk baruga yang terbuka sehingg aktivitas untuk menyampaikan aspirasi baik secara parlementer yang telah diatur dalam UUD dan secara langsung (parlemen jalan) telah mampu terwadahi.

2) Social milieu

Sebagai kantor perwakilan rakyat yang mempunyai visi demokrasi yang tertuang dalam bentuk keterbukaan, kantor ini memperlihatkan bentuknya yang terbuka dengan tidak menggunakan pintu utama pada gedungnya dan penerapan dinding setengah pada bagian hall/lobby sehingga mengesankan bentuk yang terbuka seperti bentuk baruga.

\section{Bentuk}

Secara spasial vertikal bentuk pada kasus ini mengadopsi bentuk analogi tubuh manusia.

Secara spasial horisontal bentuk denah pada bangunan ini mengadopsi bentuk persegi empat dan penggabungan dua buah persegi empat yang ditempatkan pada samping kiri dan kanan yang menjadi sayap bangunan diperuntukkan sebagai kantor administrasi.

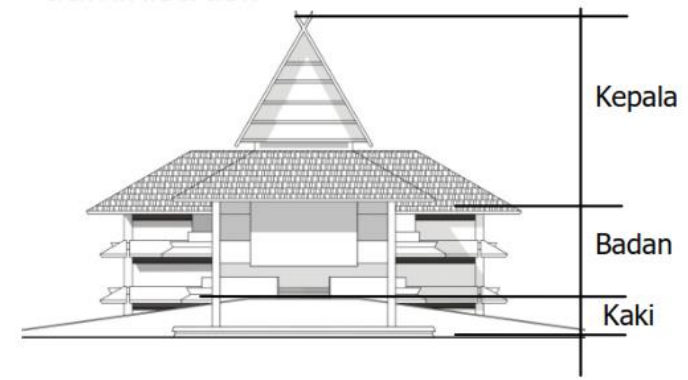

Gambar 4. Penataan Spasial Horisontal Kantor DPRD Kota Makassar

Secara Stilistika:

1) Atap

Atap pada kantor ini terdiri atas tiga bagian. Atap bagian pertama berfungsi menutup areal serambi depan, kiri, kanan dan belakang, berbentuk limasan dengan kemiringan $30^{\circ}$, lalu atap bagian kedua berfungsi menutup sayap kiri dan kanan, lalu atap pada bagian ketiga difungsikan untuk menutup areal utama (ruang sidang) yang mengadopsi bentuk atap tradisional Bugis Makassar yang memiliki timpalaja 5 susun dengan sudut kemiringan yang ditransformasi menjadi $60^{\circ}$.

2) Bukaan

Penerapan konsep arsitektur tradisional yang terbuka (tidak masif) 
diperlihatkan dengan memaksimalkan bukaan pada sisi bangunan untuk masuknya cahaya matahari dan angin/udara pada sisi UtaraSelatan terutama pada bagian lobby dan meminimalkan sisi bangunan yang berpotensi masuknya radiasi matahari pada sisi TimurBarat.

Namun, pada sisi sayap bangunan terutama pada bagian ruangan administrasi dan ruangan untuk anggota dewan sangat berkesan tertutup karena jendela-jendela yang digunakan berupa ventilasi yang memakai kaca mati.

3) Ornamen

Ornamen yang ditonjolkan pada bangunan ini adalah penonjolan struktur dan konstruksi yang diadaptasi bentuk struktur konstruksi arsitektur Bugis Makassar. Penonjolan bentuk struktur ini memperlihatkan permainan garis dan bidang horisontal dan vertikal.

Ornamen yang memperlihatkan ciri khas Rumah Bugis Makassar terlihat dari susunan timpa'laja dan pertemuan antara lisplank yang diteruskan ke atas, bentuk ini kebanyakan ditemukan pada rumah-rumah rakyat dalam masyarakat Bugis Makassar. Tidak terdapat ornamen stilasasi bentuk floral maupun fauna di bangunan ini.

\section{Struktur}

Sistem struktur yang digunakan pada bangunan DPRD Kota Makassar adalah sistem rangka (frame), yaitu struktur kolom balok beton-beton bertulang yang menerapkan kemampuan teknologi dalam mengatasi bentang lebar. Selain itu, penggunaan teknologi untuk sirkulasi vertikal dengan menggunakan lift.

\section{Kantor Bank BTN Cabang Kota Makassar Fungsi}

Sebagai kantor yang berfungsi sebagai lembaga perbankkan, kantor ini telah mencakup fungsi sebagai berikut :

\section{1) Functional frame}

Sebagai kantor yang berfungsi sebagai bank yang melayani jasa keuangan pada masyarakat, kantor ini telah mampu untuk berfungsi sebagai functional frame dengan terwadahinya aktivitas sebagai bank dengan segala fasilitas dan ruang-ruang yang mengakomodasi segala kebutuhan sebagai fungsi komersial jasa keuangan pada masyarakat

2) Social millieu

Kantor ini mampu memperlihatkan fungsi bank dengan desain kantor yang terlihat kokoh dengan tingkat keamanan yang tinggi.

\section{Bentuk}

Secara spasial vertikal, bentuk bangunan terbagi berdasar pada analogi tubuh manusia.

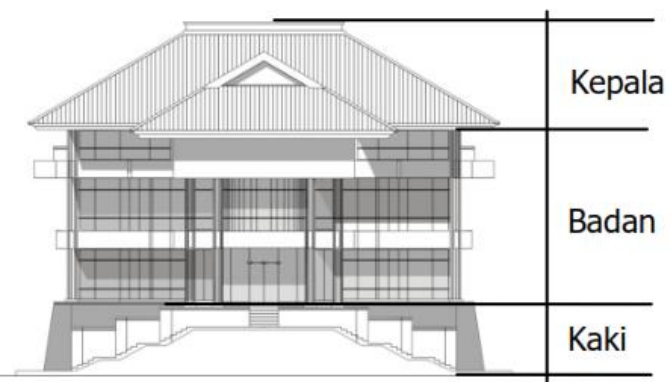

Gambar 5. Penataan Spasial Horisontal Kantor Bank BTN Cabang Kota Makassar

Untuk spasial secara horisontal, organisasi ruangnya mengikuti pola arsitektur moderen yang lebih efektif dan efisien dalam pengaturan ruangnya dengan menerapkan sistem layout kerja open plan/terbuka.

Secara stilistika :

1) Atap

Atap yang diterapkan pada bangunan ini menggunakan atap gabungan pelana dengan prisma, tanpa penggunaan timpa'laja yang merupakan ciri khas atap arsitektur Bugis Makassar. Kemiringan atap $30^{\circ}$ dan $15^{\circ}$.

2) Bukaan

Orientasi bangunan menghadap arah Timur berhadapan dengan jalan utama. Penggunaan kaca yang besar memperkuat sisi moderen pada kantor ini. Kaca tanpa bukaan dimaksudkan sebagai dinding transparan yang berfungsi untuk memasukkan cahaya, tetapi tidak berfungsi memasukkan udara dan angin karena faktor keamanan dari kantor yang berfungsi sebagai kantor bank yang membutuhkan tingkat keamanan yang tinggi.

3) Ornamen

Ornamen yang ditonjolkan pada bangunan ini adalah penonjolan struktur dan konstruksi yang diadaptasi bentuk struktur konstruksi arsitektur Bugis Makassar. Penonjolan bentuk struktur ini memperlihatkan permainan garis/bidang 
horisontal dan vertikal. Serta memanfaatkan bidang dinding kaca dengan permainan masiftransparan.

Satu-satunya ornamen yang memperlihatkan bentuk lokal adalah pertemuan lisplank yang dipanjangkan akan tetapi bukan merupakan ciri arsitektur Bugis Makassar tetapi merupakan bentuk yang terbentuk karena pengaruh dari rumah-rumah rakyat Bugis Makassar pada tahun 1980an.

Ornamen-ornamen yang digunakan hampir semuanya berbentuk geometrik yang merupakan ornamen cirri khas arsitektur moderen yang merupakan ornamen yang berfungsi struktur bukan sebagai tempelan. Tidak ditemukan unsur-unsur stilasi bentuk floral dan fauna pada bangunan ini.

\section{Struktur}

Ekspos sruktur dan konstruksi struktur balok pada kolom diadaptasi dari struktur arsitektur Bugis Makassar.

Material menggunakan material pabrikasi baik untuk konstruksi maupun elemen-elemen arsitektur lainnya.

Pada bangunan ini penggunaan unsur kayu yang merupakan material utama pada arsitektur lokal (Bugis Makassar) diminimalisir.

Pada bagian kaki/podium menggunakan batu alam yang diekspos untuk mempertegas bidang bawah/kaki bangunan. Sistem struktur yang digunakan pada bangunan Bank BTN Cabang Makassar adalah sistem rangka (frame), yaitu struktur kolom balok beton bertulang yang menerapkan kemampuan teknologi dalam mengatasi bentang lebar. Selubung dinding bagian luar menggunakan alcopanel aluminium dan penggunaan kusen-kusen kaca mati dengan aluminium menunjukkan bahan yang berkesan awet dan mahal mengesankan bangunan terlihat mewah.

Berdasarkan identifikasi dari kasuskasus yang terpilih kemudian dilakukan pembobotan untuk menilai koeksistensi arsitektur Bugis Makassar dengan arsitektur moderen pada bangunan kantor pemerintahan yang terpilih dengan nilai bobot sebagai berikut :
Tabel 1. Pembobotan Koeksistensi

\begin{tabular}{lccc}
\hline \multicolumn{1}{c}{ Variabel } & $\begin{array}{c}\text { Kasus } \\
\text { I (\%) }\end{array}$ & $\begin{array}{c}\text { Kasus } \\
\text { II (\%) }\end{array}$ & $\begin{array}{c}\text { Kasus } \\
\text { III (\%) }\end{array}$ \\
\hline Spasial Vertikal & 18 & 17,2 & 17,6 \\
Spasial Horisontal & 17,6 & 17,2 & 15,6 \\
Atap & 23,5 & 22,75 & 19,75 \\
Bukaan & 9,2 & 7,6 & 6 \\
Ornamen & 11,4 & 9 & 9 \\
Struktur & 6,8 & 66,8 & 7,2 \\
\hline \multicolumn{1}{c}{ Jumlah } & $\mathbf{8 6 , 5}$ & $\mathbf{8 0 , 5}$ & $\mathbf{7 5 , 1}$ \\
\hline
\end{tabular}

Berdasarkan hasil pembobotan di atas, dapat dilihat bahwa kantor Gubernur Provinsi Sulawesi Selatan (Kasus I) dan kantor DPRD Kota Makassar (Kasus II) dalam ukuran koeksistensi arsitekturnya bernilai baik karena telah mengadopsi dan beridentitas arsitektur tradisional Bugis Makassar dalam bentukan fisiknya. Sedangkan pada kantor Bank BTN Cabang Makassar didapatkan nilai cukup dalam ukuran koeksistensi arsitekturnya dikarenakan fungsi bangunan sebagai wadah lembaga perbankkan, ada beberapa prinsip arsitektur Bugis Makassar yang tidak diterapkan karena faktor keamanan dan kenyamanan bagi pengunjung.

\section{KESIMPULAN}

Koeksistensi arsitektur yang terjadi pada kasus penelitian pada arsitektur Bugis Makassar dengan arsitektur moderen terhadap jatidiri arsitektur lokal pada bentukan fisik sudah menyatu baik pada kantor Gubernur Provinsi Sulawesi Selatan dengan bobot 90,5\% dan kantor DPRD Kota Makassar yang berbobot $80,45 \%$ dengan tetap mengakomodasi, mengadopsi dan menerapkan unsur arsitektur lokal (Bugis Makassar) dengan unsur arsitektur Moderen sesuai komposisi yang tepat sehingga unsurunsur arsitektur tersebut tidak berkesan tempelan. Sedangkan pada kantor Bank BTN Cabang Makassar berbobot 78,65\% yang berarti penerapan koeksistesi arsitektur Bugis Makassar dengan arsitektur Moderen bernilai cukup. Unsur-unsur arsitektur yang mengalami koeksistensi pada arsitektur Bugis Makassar dengan arsitektur Moderen yaitu :

1. Pada unsur fungsi bangunan diterapkan arsitektur moderen.

2. Unsur bentuk secara spasial vertikal 
masih menerapkan arsitektur Bugis Makassar dan secara elemen horisontal diterapkan arsitektur moderen, pada elemen stilistika pada atap menerapkan unsur arsitektur tradisional tetapi pada elemen bukaan dan ornamen penerapan yang terjadi masih menerapkan arsitektur tradisional dan juga arsitektur moderen.

3. Unsur struktur, prinsip desain yang diterapkan adalah arsitektur moderen dengan penggunaan bahan-bahan pabrikasi dan teknologi.

\section{DAFTAR PUSTAKA}

Antariksa. 2010. Dampak Perkembangan Industri Terhadap Arsitektur (http://antariksaarticle.blogspot.com, diakses 22 November 2017).

Budiharjo, Eko. 2009. Arsitektur Indonesia dari Perspektif Budaya. Alumni. Bandung.

Fanani, Achmad. 2009. Arsitektur Masjid. Bentang. Jakarta.

Hidayatun, Maria I. 2008. Hakekat Ruang Dalam Arsitektur Tradisional Sebagai Satu Bentuk Jawaban dari Tantangan Alam. Prosiding Seminar Nasional Jelajah Arsitektur Tradisional Nusantara. Pusat Penelitian dan Pengembangan Permukiman. Makassar.

Jeraman, Pilipus. 2008. Transformasi Arsitektur Vernakular NTT dalam Rancang Bangun Arsitektur Kiwari. Prosiding Seminar Nasional Jelajah Arsitektur Tradisional Nusantara. Pusat Penelitian dan Pengembangan Permukiman. Makassar.

Mangunwijaya, Y. B. 1992. Wastu Citra. Gramedia Pustaka Utama. Jakarta.

Prijatomo, Josep. 1988. Pasang Surut Arsitektur Indonesia. Wastu Lanas Grafika. Surabaya.

Mardanas. 1985. Arsitektur Tradisional Daerah Sulawesi Selatan. Depdikbud. Ujung Pandang.

Soeroto, Myrtha. 2003. Dari Arsitektur Tradisional Menuju Arsitektur Indonesia. Ghalia Indonesia. Jakarta.

Wiranto. 1999. Arsitektur Vernakuler Indonesia, Perannya Dalam Pengembangan Jati Diri. Jurnal Dimensi Teknik Arsitektur Vol 27 No 2 (http://id.portalgaruda.org, diakses 10 Agustus 2017)

Yulianto, Sumalyo. 1987. Arsitektur Moderen Akhir Abad XIX dan Abad XX. Gajahmada Press. Yogyakarta. 